\title{
A estrutura sacramental da história salvífica: estudo comparado de Edward Schillebbeckx e de Luigi Giussani
}

\author{
Orientador: Abimar Oliveira de Moraes \\ Doutorando: Paulo Alves Romão \\ Área de Concentração: Teologia Sistemático-Pastoral \\ Linha de Pesquisa: Fé e Cultura
}

Esta tese tem como tema a estrutura sacramental da história salvífica a partir do pensamento comparado de Edward Schillebbeckx e de Luigi Giussani. Ela elabora as visões teológico-sacramentais desses autores, colocando em relevo elementos centrais da sacramentalidade da Revelação e da Fé. Em tais visões, colocamos em realce que a sacramentalidade da história salvífica alcança a sua plena expressão na pessoa de Jesus Cristo, porque por meio dEle nos é manifestada a totalidade do ser de Deus. Com a Revelação Deus entra em diálogo pessoal com o ser humano na história. Esse diálogo conhece seu cume e expressão definitiva em Cristo, graças à sua humanidade. No centro da história da revelação-salvação está o homem Jesus, que atua de forma verdadeiramente humana e histórica. A revelação-salvação é um acontecimento existencial no qual uma realidade divina incide sobre as realidades humanas em forma terrena e visível. O modo de Jesus se relacionar com os seres humanos, enquanto revelador do Pai é a forma privilegiada do convite ao encontro pessoal com Deus. O modo de revelar introduzido por Jesus é insuperável e, por conseguinte, normativo. Mas com a Sua morte, ressurreição e ascensão aos céus, não é mais possível encontrá-lo de forma física, corporal, ou seja, sacramental. Por isso ele fundou sua Igreja, sacramento da sua presença: de fato, a sacramentalidade da Igreja lança uma ponte sobre o afastamento ou desproporção que existe entre o Cristo celeste e a humanidade não glorificada, e torna possível o encontro humano recíproco entre Cristo e a humanidade, após a Sua ascensão. A Igreja é uma comunidade que não pode ser reduzida a uma leitura sociológica. Isto porque a Igreja, plasmada no mistério pascal, recebe o sopro do Espírito no Pentecostes e, com isso, adquire estatura para a qual foi criada, podendo, assim, assumir a missão a ela destinada: tornar presente o mistério do Filho de Deus feito homem, e convocar todos os homens para entrar na forma última e definitiva de communio-comunidade com Deus e entre si.

Palavras-chave: Cristo, Espírito Santo, sacramento, communio-comunidade. 